\title{
Long-Hours Working and Enterprise Bargaining
}

\section{Mark Wooden}

$\mathrm{R}$ ecent years have seen growing concern with the large number of hours many Australian employees appear to be working. The Australian Industrial Relations Commission in its decision on the Working Hours Case, handed down on 23 July 2002, for example, highlighted the upward trend in the average working hours of full-time employees over the past two decades. Moreover, the decision drew attention to the many adverse effects for employees, their families and the communities they live in, that could potentially result from working long hours.

That the incidence of long hours of work has risen is beyond dispute. Survey data from the Australian Bureau of Statistics (ABS) reveal that while average hours of work have changed very little in recent decades, this is the result of two forces pulling in opposite directions, with growth in the part-time employment share offsetting the rise in the average number of hours being worked by full-time employees. More importantly, it has been widely recognised that this increase in the average number of hours being worked by full-time employees is predominantly the result of an increase in the proportion of the workforce regularly working what might be thought of as excessive or unreasonable hours (for example, Dawkins and Simpson, 1994; Wooden et al, 1994; the Australian Centre for Industrial Relations Research and Training (ACIRRT), 1999; Healy, 2000; Buchanan et al, 2001; Wooden, 2001a). ACIRRT (1999:102) for example, has highlighted the marked increase in the proportion of the full-time workforce working more than 48 hours in the survey week - from around 19 per cent in the late 1970 s to 32 per cent in the late 1990s.

Many commentators have explicitly connected this extension in working hours to industrial relations reform, and especially the elevation of negotiated settlements (that is, enterprise and workplace agreements) to a position of prominence over arbitrated settlements (that is, industry- and occupation-based awards) in the determination of wages and employment conditions (for example, ACIRRT, 1999; Burgess, 1998; Heiler, 1998; Campbell and Brosnan, 1999). Heiler (1998:86), for example, has argued that the awards system acted to standardise working hours thus effectively taking hours out of competition. In contrast, under enterprise bargaining, decisions about hours are devolved to the enterprise and workplace level, undermining principles of industry and community standards. They also increase the potential for much greater diversity in working time arrangements. Indeed, the available evidence indicates that working time provisions feature prominently in agreements (ACIRRT, 1999; Department of

Mark Wooden is a Professorial Fellow at the Melbourne Institute of Applied Economic and Social Research, University of Melbourne. 
Employment, Workplace Relations and Small Business/Office of the Employment Advocate, 2000).

Enterprise agreement-making, however, only became widespread after the introduction of the Industrial Relations Reform Act 1993 (which came into force in March 1994). Further, many of the other regulatory reforms often highlighted as exacerbating trends towards longer working time, such as non-union enterprise agreements and formalised individual agreements, only assumed any significance after the introduction of the Workplace Relations Act 1996 (see Wooden, 2001b:246). It thus follows that if decentralised bargaining were a significant factor behind the erosion of working time standards, then the trend towards long hours should have accelerated in the latter half of the 1990s. In this paper this hypothesis is tested and found wanting. The paper then goes on to canvass alternative explanations for the rise in the incidence of long working hours during the 1980s and early 1990s. Following this, inter-industry data are examined with a view to determining whether trends in long hours of work since the introduction of formalised enterprise agreement-making are correlated with coverage by such agreements. The paper concludes with some observations about the likely effectiveness of attempts to exert greater regulatory control over working hours.

\section{Trends in Long-Hours Working}

In Figure 1, ABS survey data on the proportion of persons working long hours are presented for the period 1964 to 2002. As can be seen, the incidence of persons working weekly hours that are above what is generally regarded as 'standard', but below what may be thought of as 'unreasonable' (that is, between 41 and 48 hours) has not changed much. The share of employment accounted for by persons working such hours has varied between 12 and 13 per cent for most of the last two decades. In contrast, the incidence of persons working in excess of 48 hours per week is clearly higher today than two decades ago. After fluctuating at around 14 to 16 per cent for most of the 1960s and 1970s, the number of persons reporting working more than 48 hours per week rose from a low of 13.6 per cent of all employed persons in 1978 to 20.6 per cent by 1994 .

Perhaps the most interesting feature of Figure 1, however, is how this upward trend levels off after 1994. Indeed, in the most recent figures the trend appears to be downwards. The growth in the incidence of long-hours working would thus appear to be almost entirely concentrated into the period 1983 to 1994. This is of importance given that throughout much of this period, the wages and conditions of most Australian workers were set under a highly centralised regime. Furthermore, despite the (reluctant) introduction by the Australian Industrial Relations Commission of an enterprise bargaining wage principle in October 1991, it was not until 1994, when the Industrial Relations Reform Act 1993 came into force, that the many impediments to enterprise agreement-making, at least within the federal system, were removed. As observed by Hancock (1999), who was a Deputy President of the Commission at the time the enterprise bargaining principle was introduced, the Commission believed that satisfaction of the public 
interest test required that it impose strong conditions before approving any agreements. The consequence of this was that until the Government removed this public interest test requirement by legislation, the Commission approved relatively few agreements (and employers and unions alike presumably had little incentive to enter into negotiations over such agreements).

Figure 1: The Incidence of Long-Hours Working, 1964 to 2002

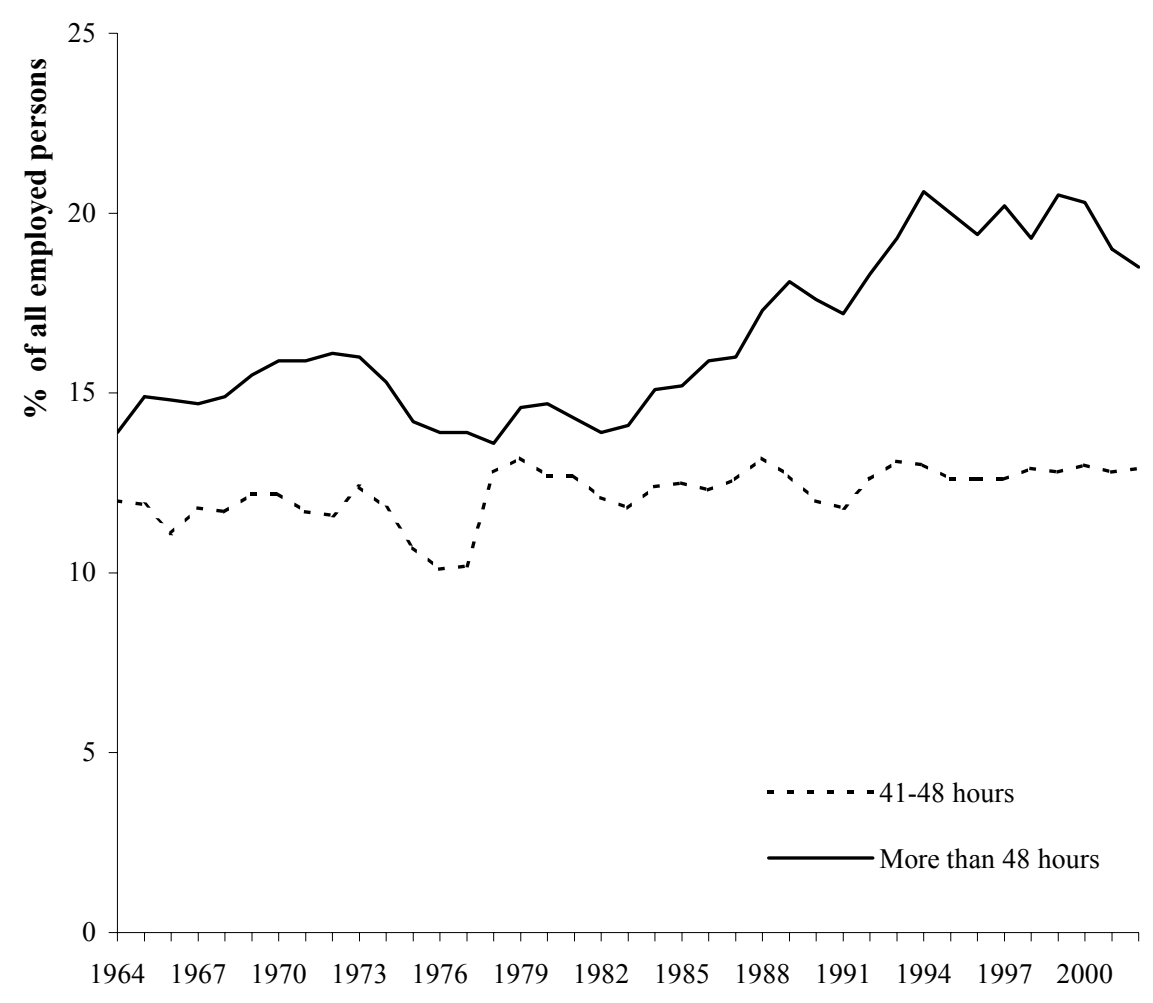

The data presented in Figure 1 would thus seem inconsistent with the hypothesis that the introduction of enterprise bargaining resulted in an increase in the number of employed persons working very long hours per week. The results of simple time-series regression analysis provide additional support for rejecting this hypothesis. Specifically, monthly data covering the period 1983 to 2002 were used to estimate a descriptive model of the trend in the proportion of employed persons working 50 hours or more each week.

The basic estimating model is a simple linear time trend taking the form:

$$
(\mathrm{LH} / \mathrm{E})_{\mathrm{t}}=\alpha+\beta \mathrm{T}_{\mathrm{t}} \quad \mathrm{t}=1 \ldots \ldots 240
$$

where LH is the number of employed persons working 50 hours or more per week, $\mathrm{E}$ is total employment, $\mathrm{T}$ is a time trend, $\alpha$ is a constant term and $\beta$ is a coefficient which measures the size of the relationship between the share of long-hours 
working in total employment and time (it measures the slope on the line of best fit through the data). In addition, since the data are monthly, also included in the equation are 11 month dummies to hold constant any seasonal effects. ${ }^{1}$

This functional form, however, is quite restrictive. Specifically, it assumes that the rate of change in the incidence of long-hours working is stable over time. To allow for the rate of change to vary over two sub-periods, equation (1) is respecified as follows:

$$
(\mathrm{LH} / \mathrm{E})_{\mathrm{t}}=\alpha+\beta \mathrm{T}_{\mathrm{t}}+\delta \mathrm{D} \cdot \mathrm{T}_{\mathrm{t}}+\phi \mathrm{D} \quad \mathrm{t}=1 \ldots . .240
$$

where $\mathrm{D}$ is a dummy variable that takes the value 0 for all observations during the first sub-period (1983 to 1993) and value 1 for all observations during the second sub-period (1994 to 2001). The estimated size of $\delta$ measures the extent of change in the relationship between long-hours working and time. If the estimate of this parameter is insignificantly different from zero then it can be concluded that the time trends for the two sub-periods are essentially the same.

The results are presented in column I of Table 1, and provide strong support for the presence of a structural break, as reflected in both the highly significant coefficient on the interaction term (D.T) and a Chow test, which compares this model with the more restrictive model that assumes a simple linear trend. More importantly, the estimated coefficients on the time trend (T) and the multiplicative interaction term indicate that after rising during the period 1983-1993, the proportion of employed persons working 50 hours or more has subsequently been falling. This is reflected in the negative differential between the coefficients on $T$ and on D.T.

The specification, however, fails to pass a general test for misspecification (the RESET test). One obvious problem with the specification is that the dependent variable is constrained to lie between 0 and 100, violating the assumption of linearity required for least squares estimation. This problem, however, is easily overcome by use of the logistic transformation. That is, the dependent variable is transformed to become:

$$
\ln [(\mathrm{LH} / \mathrm{E}) /(100-\mathrm{LH} / \mathrm{E})]
$$

The results of re-estimating equation (2) using this alternative form for the dependent variable are reported in column II. These results continue to reveal clear evidence of a marked change in the pattern of growth in the incidence of extended working hours. Note further that as expected, the size of the RESET statistic declines and is now no longer statistically significant.

1 Since the data relate to actual hours worked in the survey week, seasonal effects are quite pronounced, with the average proportion of the workforce working 50 hours or more in the January survey week being only 67 per cent of the average proportion in the December survey week. 
Table 1: Trends in Incidence of Working 50 Hours or More per Week, 1983-2002: OLS Regression Results

\begin{tabular}{|c|c|c|c|}
\hline \multirow[t]{2}{*}{ Variable } & \multirow{2}{*}{$\begin{array}{c}\text { Dependent } \\
\text { variable: } L H / E \\
I\end{array}$} & \multicolumn{2}{|c|}{$\begin{array}{c}\text { Dependent variable: } \\
\ln [(L H / E) /(100-L H / E)]\end{array}$} \\
\hline & & $I I$ & III \\
\hline \multirow[t]{2}{*}{ Constant } & 9.411 & -2.184 & -2.264 \\
\hline & $(0.282)$ & $(0.023)$ & $(0.370)$ \\
\hline \multirow[t]{2}{*}{ Time trend $(\mathrm{T})$} & 0.035 & 0.0027 & 0.0036 \\
\hline & $(0.002)$ & $(0.000)$ & $(0.001)$ \\
\hline \multirow[t]{2}{*}{ Structural break dummy (D) } & 6.237 & 0.455 & 0.589 \\
\hline & $(0.583)$ & $(0.050)$ & $(0.081)$ \\
\hline \multirow[t]{2}{*}{ Interaction term (D.T) } & -0.042 & -0.0032 & -0.0043 \\
\hline & $(0.004)$ & $(0.000)$ & $(0.001)$ \\
\hline \multirow[t]{2}{*}{ Employment to population ratio } & & & 1.365 \\
\hline & & & $(0.529)$ \\
\hline \multirow{2}{*}{ Married female employment share } & & & -3.158 \\
\hline & & & $(1.759)$ \\
\hline Adjusted R-squared & 0.831 & 0.815 & 0.819 \\
\hline Model F & 85.012 & 76.134 & 68.665 \\
\hline Durbin-Watson & 1.862 & 1.800 & 1.846 \\
\hline $\operatorname{Reset}\left(\mathrm{F}_{3, \mathrm{n}-\mathrm{k}}\right)$ & 8.945 & 3.606 & 4.917 \\
\hline Chow test $\left(\mathrm{F}_{2, \mathrm{n}-\mathrm{k}}\right)$ & 56.160 & 33.279 & 26.745 \\
\hline
\end{tabular}

Notes: 1. LH/E has a mean value of 16.69 and a standard deviation of 2.51 .

2. The term D takes the value 0 for all observations during the period 1983 to 1993 inclusive, and the value 1 for all observations thereafter.

3. Also included, but not reported here, were 11 month dummies (to capture seasonal variations).

4. Standard errors are shown in brackets.

Source: Time-series data from the ABS Labour Force Survey available on either Data Cube (6291.0.55.001 Labour Force, Selected Summary Tables, Australia, Monthly) or Spreadsheet (6291.0.55.001 Labour Force, Australia, Detailed - Electronic Delivery).

Further testing also revealed that this result was robust to changes in specification. Thus in column III the results of estimating an equation that has been augmented by the inclusion of the employment to population ratio (E/P) and the share of married females in total employment are reported. E/P was included in an effort to capture cyclical effects, and is expected to be positively signed. That is, we expect employers to exert greater pressures on workers to work long hours when labour markets are tight. ${ }^{2}$ The share of married females in total employment is expected to be negatively signed as females, and especially married females, continue to assume most responsibility for household production and hence will, on average, be both less willing and less able to work long hours on a regular basis. Both of these variables were statistically significant and had

2 I also experimented with the unemployment rate and the unemployment to population ratio as alternative proxies for the influence of the business cycle. The estimated coefficients on both variables were of the expected sign, and were at least of marginal significance. 
the expected sign. Their inclusion, however, had only a small impact on the other estimated parameters, and evidence of a clear structural break remains.

Finally, sensitivity testing revealed that the overall model fit could be slightly improved upon by setting the date for the timing of the structural break back a few months - to April 1994. The impact on the estimated coefficients, however, is negligible.

There are thus good reasons to be sceptical about the claim that enterprise bargaining has intensified pressures on many workers to increase the hours they work. It, however, needs to be recognised that the simple analysis reported here does not establish causation. Indeed, a more conclusive answer almost certainly requires the development and estimation of a formal model of labour supply, which is well beyond the scope of this paper.

\section{Rise in Long Hours Working Between 1983 and 1994}

Patterns of working time in Australia have clearly undergone enormous changes in recent decades. In terms of the growth in the incidence of long-hours working, however, this is not a recent phenomenon. Indeed, it would appear that all of the growth occurred during the period 1983 to 1994. A serious consideration of the reasons why so many Australians work long hours today thus needs to provide an explanation for why the hours for so many full-time workers rose during this period. This is no simple task, and is not one that can possibly be done justice here. Nevertheless, in an earlier commentary on the growth in average hours being worked by full-time workers during the 1980s and early 1990s, Wooden et al. (1994) posited three possible explanations. First, changes in the composition of employment favouring jobs traditionally associated with long hours of work. Second, a general shift in bargaining power towards employers as a result of rising competitive pressures and greater job insecurity. Third, the impact of the Accordbased incomes policy which, by restraining real wages growth, provided workers with incentives to use increased hours as a mechanism for obtaining higher incomes, whether it be immediate, via taking second jobs, or deferred, through enhanced promotion prospects. Only the latter explanation now appears to be consistent with the evidence.

The first explanation is most easily disposed of. As reported in Table 2a, over the period 1986 to 1995 , the proportion of persons working long hours increased in all major occupation categories. ${ }^{3}$ Indeed, if the proportion of persons within each occupation category working in excess of 48 hours had remained unchanged at its 1986 level, the changes in the occupational composition of employment that occurred over the next decade would actually have led to a slight fall in the overall incidence of long-hours workers. In other words, none of the net increase in the incidence of long-hours work over this period was the result of

3 The choice of this time period is dictated by major changes in the occupation classification system used by the ABS in both 1986 and 1996. Nevertheless, it is fortunate that it roughly coincident with the period when the incidence of long-hours working was rising. 
changes in the occupational composition of employment (at least not when calculated at a very broad level of occupation aggregation). Exactly the same conclusion is reached if the industrial composition of employment is considered. As for occupational composition, persons working more than 48 hours per week increased their share of employment in all industry divisions during the 1980s and early 1990s. Again the net increase in the incidence of long-hours working cannot be explained by changes in the industrial composition of employment.

Of some interest, Table $2 b$ indicates that since 1996 changes in the broad occupational composition of employment, and especially the relative growth in the employment of professionals, have actually favoured further increases in the share of long-hours workers in total employment. The decline in the incidence of longhours working since the mid-1990s has thus occurred despite unfavourable shifts in the composition of employment. It is also worth noting that unlike the preceding decade, the decline in the incidence of long-hours workers since 1996 has not been evenly distributed across occupations, and has been concentrated in the managerial and professional occupations.

The second explanation is also less than convincing. As observed by Wooden (2001b), there is very little evidence that levels of perceived job security among Australian workers have been deteriorating over time (see also Borland, 2001). Indeed, regularly collected opinion poll data reveal that since 1975 the proportion of workers who believe that their own jobs are at risk has increased only slightly. Fears about job loss vary with the economic cycle, but the longterm level has been largely time invariant. This explanation can thus help explain the short to medium-term cyclical variation in hours of work, but it cannot explain both the sustained rise in long-hours working in the 1980s and the cessation of that trend since 1994. Similarly, other demand-side explanations based on changing levels of uncertainty in product markets or on growth in non-wage costs (for example, as a result of changes to unfair dismissal laws and the introduction of the Superannuation Guarantee) are also inconsistent with the observed structural break that occurred in the mid-1990s.

Thus what is left is essentially a supply-side explanation. Working hours rose during the 1980s and early 1990s in response to the lack of other mechanisms for obtaining increases in income. Once real (hourly) wages again began to rise (following the introduction and spread of enterprise bargaining), these pressures subsided. In other words, changes in hours worked may reflect nothing more than movements along a backward-bending labour supply curve. This too, however, seems overly simplistic. Real earnings for full-time employees in Australia, for example, did not decline much during the 1980s, suggesting that individual labour supply must have been increasing. We thus need a theory to explain why labour supply curves might have been gradually shifting to the right during this period. One answer is suggested by the work of George (1997). In explaining trends in working time in the USA, he argued that in the absence of sustained increases in real wages, workers found it necessary to work longer hours in order to satisfy increased preferences for goods and services, preferences that are continuously being stimulated by product marketing and advertising. 
Table 2a: Incidence of Long Hours Working and the Occupational Composition of the Workforce, 1986 and 1995

\begin{tabular}{lccccc}
\hline \multirow{2}{*}{ Occupation group } & \multicolumn{2}{c}{ August 1986 } & & \multicolumn{2}{c}{ August 1995 } \\
\cline { 2 - 3 } \cline { 5 - 6 } & $\begin{array}{r}\text { \% working } \\
\text { >48 hours }\end{array}$ & $\begin{array}{c}\text { Employment } \\
\text { share (\%) }\end{array}$ & $\begin{array}{c}\text { \% working } \\
\text { >48 hours }\end{array}$ & $\begin{array}{c}\text { Employment } \\
\text { share (\%) }\end{array}$ \\
\hline Managers \& administrators & 48.8 & 11.0 & & 51.6 & 10.4 \\
Professionals & 19.1 & 12.0 & & 26.5 & 14.1 \\
Para-professionals & 9.9 & 5.9 & & 14.2 & 5.8 \\
Tradespersons & 15.6 & 16.8 & & 22.5 & 14.5 \\
Clerks & 3.7 & 17.3 & & 7.6 & 16.6 \\
Salespersons \& personal service & 12.7 & 13.8 & & 13.2 & 16.7 \\
workers & & & & 24.6 & 7.2 \\
Plant and machine operators \& & 17.8 & 7.9 & & 10.3 & 14.8 \\
drivers & 8.4 & 15.4 & & 20.0 & 100.0 \\
Labourers \& related workers & 15.9 & 100.0 & & \\
TOTAL & & & & & \\
\hline
\end{tabular}

Source: $\quad$ ABS, The Labour Force, Australia (cat. no. 6203.0), August 1986 and August 1995 issues.

Table 2b: Incidence of Long Hours Working and the Occupational Composition of the Workforce, 1996 and 2002

\begin{tabular}{|c|c|c|c|c|}
\hline \multirow[t]{2}{*}{ Occupation group } & \multicolumn{2}{|c|}{ August 1996} & \multicolumn{2}{|c|}{ August 2002} \\
\hline & $\begin{array}{l}\% \text { working } \\
>48 \text { hours }\end{array}$ & $\begin{array}{l}\text { Employment } \\
\text { share }(\%)\end{array}$ & $\begin{array}{l}\% \text { working } \\
>48 \text { hours }\end{array}$ & $\begin{array}{c}\text { Employment } \\
\text { share (\%) }\end{array}$ \\
\hline Managers and administrators & 49.3 & 7.5 & 46.4 & 7.4 \\
\hline Professionals & 23.3 & 16.7 & 21.3 & 19.0 \\
\hline Associate professionals & 34.3 & 10.4 & 30.2 & 11.6 \\
\hline $\begin{array}{l}\text { Tradespersons \& related } \\
\text { workers }\end{array}$ & 20.7 & 13.8 & 22.1 & 12.6 \\
\hline Advanced clerical \& service & 5.2 & 4.8 & 5.8 & 4.2 \\
\hline $\begin{array}{l}\text { Intermediate clerical, sales \& } \\
\text { service }\end{array}$ & 8.0 & 16.8 & 7.6 & 17.1 \\
\hline $\begin{array}{l}\text { Intermediate production } \& \\
\text { transport }\end{array}$ & 21.6 & 9.6 & 21.6 & 8.5 \\
\hline $\begin{array}{l}\text { Elementary clerical, sales \& } \\
\text { service }\end{array}$ & 7.8 & 10.4 & 5.1 & 10.1 \\
\hline Labourers and related workers & 8.7 & 10.1 & 8.6 & 9.6 \\
\hline TOTAL & 19.4 & 100.0 & 18.5 & 100.0 \\
\hline
\end{tabular}

Source: ABS, The Labour Force, Australia (cat. no. 6203.0), August 1996 and August 2002 issues. 
It is thus this latter explanation that is held out here as offering most potential for explaining the recent Australian experience. It helps explain why working hours rose when real wages were held in check in the 1980s and it also helps explain why, when real wages began rising again, the number of hours being worked levelled off but did not actually fall, at least not for quite a long time.

\section{Industry Bargaining Coverage and Long-Hours Working}

The discussion and analysis of the preceding sections reveals that the adoption and spread of enterprise agreements has actually coincided with declines in the incidence of long-hours working. Moreover, enterprise bargaining, to the extent that it has facilitated real wages growth, may have indirectly contributed to that decline. But can it be concluded that enterprise bargaining has not had any effects in the opposite direction? That is, while real wages growth may have reduced the supply of workers prepared to work long hours, enterprise bargaining may have contributed to an increase in the demand by employers for such workers.

As a crude test of this hypothesis, industry differences in the coverage of employees by collective agreements (based on survey data collected by the ABS from employers about methods for determining pay) were correlated with industry differences in both the incidence of long hours of work and change in the incidence of long-hours working since $1994 .{ }^{4}$ The data are summarised in Table 3.

The first point to note is that the share of employees covered by collective agreements is inversely correlated with the incidence of long hours of work $(\mathrm{r}=-0.36)$, with the industries where enterprise agreements have the greatest coverage tending to be also industries where comparatively few persons are working more than 48 hours per week. This is not unexpected, and reflects the fact that the types of employees who are most likely to work extended hours (that is, managerial and professional employees) are much more likely to rely on individual agreements for wage increases. Second, and more importantly, growth in the incidence of long hours of work since 1994 is positively associated $(\mathrm{r}=0.46)$ with coverage by collective agreements. Thus Table 3 shows that marked rises in the incidence of long-hours working occurred in the electricity, gas and water, communication services, and mining industries, all industry divisions with above average rates of coverage by enterprise agreements. In contrast, large declines were recorded in the retail trade, and property and business services sectors, where coverage by enterprise agreements is less pervasive.

\footnotetext{
4 Ideally we would compare two data points that are before and after the introduction of the enterprise bargaining principle. The industry classification system, however, was changed in August 1994 thus precluding comparisons between periods before and after that time.
} 
Table 3: Incidence of Long Hours Working and Coverage by Collective Agreements by Industry

\begin{tabular}{|c|c|c|c|c|}
\hline \multirow[t]{2}{*}{ Industry division } & \multirow{2}{*}{$\begin{array}{l}\text { \% employees } \\
\text { covered by } \\
\text { collective } \\
\text { agreements } \\
\text { May } 2002\end{array}$} & \multicolumn{2}{|c|}{$\begin{array}{c}\% \text { of employed } \\
\text { working } \\
>48 \text { hours }\end{array}$} & \multirow[t]{2}{*}{$\begin{array}{l}\text { Change in } \\
\% \text { working } \\
>48 \text { hours }\end{array}$} \\
\hline & & $\begin{array}{c}\text { August } \\
1994\end{array}$ & $\begin{array}{c}\text { August } \\
2002\end{array}$ & \\
\hline Mining & 40.5 & 34.1 & 38.4 & 4.3 \\
\hline Manufacturing & 37.5 & 20.3 & 18.9 & -1.4 \\
\hline Electricity, gas \& water & 78.1 & 10.6 & 18.1 & 7.5 \\
\hline Construction & 23.1 & 26.7 & 25.4 & -1.3 \\
\hline Wholesale trade & 7.9 & 23.8 & 23.3 & -0.5 \\
\hline Retail trade & 30.3 & 19.8 & 14.3 & -5.5 \\
\hline Accommodation, cafes \& restaurants & 6.8 & 18.6 & 17.7 & -0.9 \\
\hline Transport \& storage & 40.3 & 27.1 & 28.4 & 1.3 \\
\hline Communication & 69.1 & 14.8 & 19.5 & 4.7 \\
\hline Finance & 50.0 & 14.8 & 16.3 & 1.5 \\
\hline Property and business services & 11.7 & 26.1 & 22.4 & -3.7 \\
\hline Government administration \& defence & 86.6 & 9.5 & 8.2 & -1.3 \\
\hline Education & 83.5 & 16.2 & 15.5 & -0.7 \\
\hline Health \& community services & 49.5 & 9.8 & 8.5 & -1.3 \\
\hline Cultural \& recreational services & 31.2 & 17.3 & 16.2 & -1.1 \\
\hline Personal \& other services & 42.6 & 17.4 & 15.7 & -1.7 \\
\hline TOTAL & 38.2 & 20.6 & 18.5 & -2.1 \\
\hline
\end{tabular}

Sources: ABS, The Labour Force, Australia (cat. no. 6203.0), August 1994 and August 2002 issues, and ABS, Employee Earnings and Hours, Australia, May 2002 (cat. no. 6306.0).

Arguably such findings imply that in the absence of enterprise agreements, the recent decline in the incidence of long-hours working might have been even greater. However, a number of qualifications must be noted. First, the data are far from perfect. Most obviously, while the data on agreement coverage relate to employees, the data on hours of work relate to all employed. Second, the data used here to measure coverage by collective agreements do not actually measure the number of employees covered by such agreements. Rather, they identify the number of employees who had the main part of their pay set by collective agreements (or enterprise awards). There will, therefore, be other employees whose pay depends largely on individual arrangements, but who nevertheless are still covered by collective agreements. Third, with such a small number of observations, the size of the observed correlation is highly sensitive to outliers. Exclusion of the electricity, gas and water, and communication services industries, for example, sees the size of the correlation coefficient drop markedly. In both 
these cases there are good reasons to believe that the forces driving up hours of work lie in the increased exposure of these industries to competitive forces rather than in enterprise bargaining. Specifically, in both these industries the level of private ownership has risen markedly since the early 1990s.

In summary, there is some evidence to suggest that industries where collective agreements are most pervasive have also been the industries where the incidence of long-hours working has continued to rise in recent years. This evidence, however, is relatively weak, especially given that this correlation is largely driven by two relatively small industries (at least in terms of employment), both of which have undergone major transformations in their competitive structures over the last decade or so.

\section{Conclusion}

The fixation with recent industrial relations reforms as the key source of variations in working time patterns has not been helpful. All of the net increase in the proportion of employed persons working long hours occurred during the period 1983 to 1994, and hence prior to the introduction of enterprise agreements at most workplaces. This is not to say that labour market regulation can have no consequences for working time outcomes. Indeed, the most likely explanation for the increased incidence of long-hours working during the 1980s has its root in regulation. In contrast to popular belief, the rise in the number of persons working very long hours was almost certainly a response to a more (rather than less) centralised system for setting wages and other employment conditions. The operation of a centralised incomes policy in the 1980s, by holding down real wages, forced workers to rely on other mechanisms, such as sending other family members into the workforce and seeking additional working hours, in an effort to support desired consumption patterns.

By the same line of reasoning, it follows that with the growth of real wages during the 1990s we should have witnessed a decline in the number of persons willing to work long hours of work. The proportion of employed persons working more than 48 hours per week, however, while falling, remains high -18.5 per cent in August 2002. Moreover, other ABS data, from the Forms of Employment Survey for November 2001, continues to reveal clear preferences for working fewer hours among many of those in full-time jobs -34 per cent of full-time workers expressed a preference for fewer hours of work, up from 27 per cent in August 1998 when this survey was first conducted. A clear mismatch between the actual and desired working hours for many workers, and especially those still working long hours each week, thus persists.

Such observations suggest that more decentralised bargaining arrangements may have reduced the supply of workers who are willing to work long hours on a regular basis, but without having the same impact on the demand for such working arrangements by employers. Indeed, some (albeit weak) evidence was uncovered to suggest that those industries most affected by enterprise, and workplace-level, agreements have also been industries where the trend towards long-hours working 
has continued into the $21^{\text {st }}$ century. It thus may not be correct to conclude that the impact of enterprise bargaining on long-hours working has only been in one direction. That is, the types of working time provisions that have been typically associated with enterprise agreements (such as wider spans for ordinary hours and the averaging of working hours over periods longer than a week), may have made extended hours a more attractive employer strategy for meeting labour requirements. It is possible, therefore, that enterprise bargaining has intensified the conflict between workers and employers over working time.

Nevertheless, given the wide diversity in the personal circumstances of individuals and their families, more decentralised bargaining structures still appear to offer the best vehicle for achieving a better balance between actual and preferred working hours arrangements. 'One size fits all' approaches involving the use of awards to impose standards on all employers and employees, such as advocated by the Australian Council of Trade Unions and by many industrial relations academics (for example, Buchanan and Bearfield, 1997), could actually end up making more workers worse off than it makes better off.

Finally, it is not at all obvious that the imposition of regulatory limitations or standards on their own would have a large effect on the incidence of long hours of work. For a start, many of the individuals working these long hours tend to be in occupations that are not much affected by regulation (most obviously managers and professionals, but there are also many other workers at the other end of the income spectrum for whom award-based regulation is unlikely to be effective). Second, many of the additional hours are not directly paid for on an hourly basis and hence presumably not recorded, thus making the policing of hours restrictions difficult. $^{5}$ Third, but related to the preceding point, many of these extra hours are worked at home, which in most instances will be beyond the reach of regulation. Fourth, restrictions can always be circumvented by taking additional part-time jobs.

\section{References}

Australian Centre for Industrial Relations Research and Training (1999), Australia At Work: Just Managing?, Prentice Hall, Sydney.

Borland, J. (2001), 'Job Stability and Job Security', pp. 142-159 in J. Borland, R. Gregory and P. Sheehan (eds), Work Rich, Work Poor: Inequality and Economic Change in Australia, Centre for Strategic Economic Studies, Victoria University, Melbourne.

Buchanan, J. and S. Bearfield, (1997), Reforming Working Time: The Future of Work, Brotherhood of St Laurence, Melbourne.

5 According to the ABS Employment Arrangements and Superannuation Survey conducted in 2000, well over half of all workers working 'extra' hours during the preceding four weeks were not directly paid for those hours. Of course, this does not mean that such work is not remunerated. Instead, remuneration occurs in the form of either a larger total remuneration package or as deferred rewards (for example, increased promotion opportunities or enhanced future employment prospects). 
Buchanan, J., B. van Wanrooy, G. Considine and T. Bretherton (2001), 'Working Time Arrangements in Australia: A Statistical Overview for the Victorian Government', Unpublished Report, ACIRRT, University of Sydney.

Burgess, J. (1998), 'Working-time Patterns and Working-time Deregulation in Australia', Economic Papers 17(2):35-47.

Campbell, I. and P. Brosnan (1999), 'Labour Market Deregulation in Australia: The Slow Combustion Approach to Workplace Change', International Review of Applied Economics 13(3):353-394.

Dawkins, P. and M. Simpson (1994), 'Work, Leisure and the Competitiveness of Australian Industry', International Journal of Manpower 15(9):38-76.

Department of Employment, Workplace Relations and Small Business/Office of the Employment Advocate (2000), Agreement Making in Australia Under the Workplace Relations Act, 1998 and 1999, DEWRSB, Canberra.

George, D. (1997), 'Working Longer Hours: Pressure from the Boss or Pressure from the Marketers', Review of Social Economy 55(1):33-65.

Hancock, K. (1999), 'Labour Market Deregulation in Australia', pp. 38-85 in S. Richardson (ed.), Reshaping the Labour Market: Regulation, Efficiency and Equality in Australia, Cambridge University Press, Melbourne.

Healy, E. (2000), 'The Shift to Long Working Hours: A Social and Political Crisis in the Making', People and Place 8(1):38-49.

Heiler, K. (1998), 'What has Happened to Standard Hours of Work in Australia? or Do We Need to Bring Back the Bundy Clock?', pp. 75-99 in B. Cass and R. Couch (eds), Divided Work, Divided Society: Employment, Unemployment and the Distribution of Income in 1990s Australia, Research Institute for Humanities and Social Sciences, University of Sydney.

Wooden, M. (2001a), 'The Growth in Unpaid Working Time', Economic Papers 20(1):2944 .

Wooden, M. (2001b), 'Industrial Relations Reform in Australia: Causes, Consequences and Prospects', The Australian Economic Review 34(3):243-262.

Wooden, M., J. Sloan, S. Kennedy, P. Dawkins, and M. Simpson, (1994), 'Work Sharing and Unemployment', National Institute of Labour Studies Working Paper Series no. 129, Flinders University, Adelaide.

The author thanks Simon Freidin for assistance with the preparation of some of the data used in the article, and the editor, Franco Papandrea, and two anonymous referees for helpful comments and suggestions. 